何 過り

ほ程出わ

どはされ

かミれわ

のク、れ

高品何は序

教に加頃

育はの

卒、職高 説

業何場等

者 5 に教

をか吸姢

雇の收機

用職さ関

し業れ加

的 $\tau$ b

六行年

之流々

吉過何

る $\exists$ 程 が

雇ンをし

用を観か

主求察の

とめし量

のるての

両卒い卒

者業る業

行者こ者

的テい力でが

にムうのき

はが三需る。労

そ労ら要。劺

の働の・ま市

時市シ供た場

々場ス給こを

のにテとれ媒

高向么いを仝

等け間うマと

教ての次クし

㕕了均元口て

シウ衡で的

スト調のな相

テ・節、互

ムプ過高べに

のッ程等ル調

量卜だ教か整

的すと䏍らさ

規るも洎れ

模労い不秃て

に㗢いテば行

よ力う厶、く

つのるとこ過

て供。経の程

規給高済過 と

定量等シ程見

さ教杀はる

れ、充テ南学

て直シ㕕労

か業 \&一給形者高て

け構とのの成の等計こ

て造う仮均す雇教量の

のかく説衡る用育的小

七ら分的水加市卒分論

つ規析状準を場業析で

の定を態を計の者をは

社さ試とと量拡を試高

会れみはり的大吸み等

でてた定出にに収、教

$の<。$ 常す明結寸そ㕕

職るま状たらびるこ卒

業高ず態めかつ度に業

構等一で、にく合見者

造教九の二す傾のらの

の吉六均つる向高れ需

変卒 $\bigcirc$ 衡のた性いる給

動業年で仮めの職若過

を者とあ説、㐫業芉程

もにいり的ゴるののに

之対 う、状 1 こ相経関

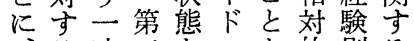
る時三をンを的則る

高需点の設流指比を実

等要を仮定の摘重と証 教々選説し分しがり的 育のび的、析た搪出検 卒定、状そ手。大乙討 業常二態れ法こしたを 者状七とぞをうれ角しそそ試 需の国動のいたののた 要もの態場て職結結 堌とデ的合々業果果ま 供の夕衡つれ造他経最 給均をでいをのの済初 增衡\&市て計変条水に の水之るの量動件準経 な準飞。均的汃がの済 加を、次衡に高等上変 でと各に条確等し昇動 のり国こ件定教い過過 動出ののにし䏍限程程 態し高一つた卒りにに 的た等般い。業、おお 均。教的て次者経いけ 衡次䏍定のにに済てる 水にの式一高対水は職 準一量を般等す準、業 を九的も的教るの一構 と六構と定育ど上般造 り $\bigcirc$ 造に式卒れ昇的の 出年々実化業だはに变 乙かそ証を者湆高動 たらの的試のの等つ傾 七社デ需需教て向 ○会1た要要育、に 年会夕。増卒元つ に職に第供を業来い

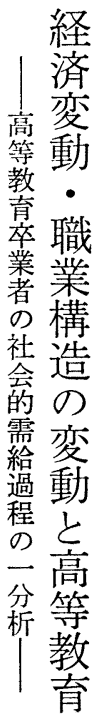

潮

木

守 
いも題に登こ広ののてて数に作のを可は要的市構教り、 かっは、場で範問間こ知の登り行求能な量に場造育

にぱ、自守はな題ののる主場出動め性いと非のに卒他 変らこ㞯る何下に労小こ体すさのるが、が計状よ業方 動マこの諸が位関衝論とのるれ両高含と、画況つ者諸 さクで選々し領し力の吕選諸る者等まいあ的にてに々 せ口は択のか域てのテで択々。な教れらら経よ規対の るレ一行主のを完供、き行のわい䏍て点か済っ定す雇 かべ応動体領一全給マる動主机し卒おでじ体てさる用 、ル除をが域つな・は。の体わは業りあめ制規れ需主 その外い、限一体需、結のれ二者、る均の定、要体 し問しか労定つ采要こ果複が方の不。衡む更量か て題てに働を検的とうを雑日早行均そがをれにはら 第でお変市し討理いしな頃変動衡ことでて短、構 三、く動場てし論うたた選観容尔にれはい期長成

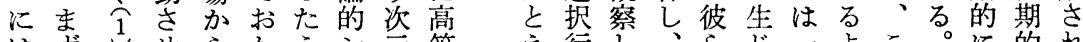

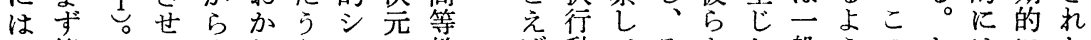
こ第こる発ねえ土で教壮動てそをた般うのたはにた

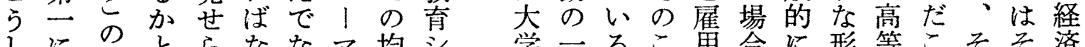
しにのとらななマ均方学一るこ角合に形等こそそ済 たは少いれらけを衡ス卒部のとしに何で教こののシ 形経論っるなれ作のテ業分はをよはらは㕕で時時ス で済でたるい諸い問么者で、通う、か制卒重々々テ

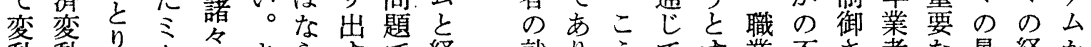
動動あクのまらすで経就りうてす業不さ者な景経か すがあ怙口情ずなにあ済職、し新る的均れのこ気済ら る職げ次情労いはる法をたた諸ホ衡て供と変水生 職業る元報衝の、。統う労な々涪がい給は動準じ

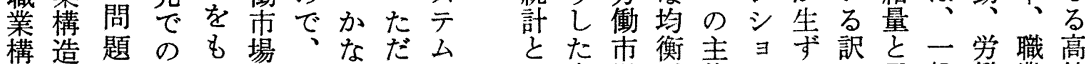

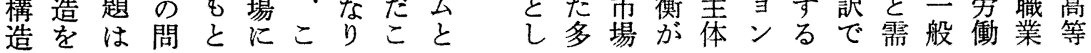

ろ抽らで領学变とはの業他ン多力若関と教すがこか

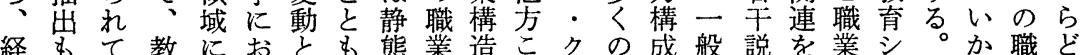
経もて教におとも態業造こクの成般説を業ジか職ど 済、は玄おい職に的構なれラ奏比に明問構不つな業れ 学分きシいて業職比造いには証のこすう造テまる構だ は析たスても構業較し対ク的変れる、㕕り形造け 経理がテは十造構研なはし、理動まなとのとこでのの 済論、ム、分の造究い職てサ論とでらい関のこ均変高 変のそと中展両ががし業社イ的い経ばう連間で衡動等 動 構の䅅卒開者い進は構会モ成う済、点をにの卞か教 々築多済者さをかめ職成学ン果問学次に問職分るら充

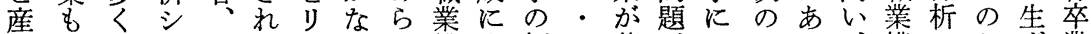
業十はス高てンるれ構す領ク蓄がおよる、構のかず業 構分記テ卒きク傾て成え域ズ積という。そ造基、る者 造に述台者たさ向きのらにネさりてにこしと本こ需に

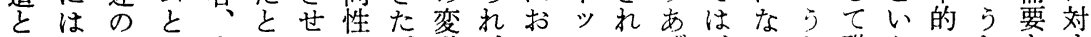
のな段の大はたの。動、いッてげ、るし職うアしとす 関さ階接卒い分もし傾一てのきら経。た業媒さた高る 連れに点者い析之か向つは仮たれ済分構介デ三等需 分てとにながはでしにの、説。、変析造項アう教要 析こどかどた、変な関社主とそこ動手とをはの育が はなまかのい経動が侌となののに続高設、下シ生 行かっわ就。済导らるなしる成領之等定経位 なってる職ま学る、時いてて果域も教し済領テる ったお問先たにか経系し分示はにな效、域么か $\tau$ 七 題分教おと済列は析さ例おう きつ、架析育いい水分複のれえい産 たま経とと社てう準析数単てばて業 がる験りい会も、のなの位いコは別 、と則あう学社経変い社がる। 労 そこのげ形の会済動し会職。リ数衝 ら音経不加 いス済テ検 ら第 にテシム討 の 至 つムスとを供に いとテ高限給は てのム等定と 
る他べえれにな構のも

相なルれほよ形成証つ一

互らでばどつに比拠た般

関な行、変て組のと労に 連いなコ動規み増し衝よ 性。弓， 守な加て力

が一たリるさおとしに

存体矢ンの和すい壮対高

在一証・ かてならし吉度

寸つ研ク、いら経ばる花

るの究ラそるば験、需し

の社を、れの、的職要た

か会、クをか一事業が産

の職や問、つ実構増業

そ経業サう経の㤎造大社

れ済構イこ済社举にす会

を水造モと水会げおるに

ま準のンに準のらけと拉

ずとレ・帰の職れるさい

検職べク着変業るつれて

討業ルズす動構。專ては

し構にネるに造こ悶い

な造おッ。よがの的る高

けといッこっど閣・。度

れのてがのてれ題技その

ば間行産問職ほほ術し知

なにな業題業どよ的て識

らはう構は構経り職そ

ないこ造い造済一業の技

いかと市いは水般华

なにレかど淮的のつを
教題三論教な関業経育の 育をにで充い連者済社分 シとはは社限変会析 二スり職、会りそ需動学を テ出業ま学、しし要とは職 厶し構ずの完て・リ職業 緕か、造最三結更供ン業構 ら最の初者しに給ク構造 の後変にのなそのさ造に 供に動経交いの均せをま 給こか済点。職衡る分で と ら変のつ菜の点析押 のし生動一ま構問にのし 均たずが領り造題お単進 衡高る職域こ崖い位め の等高業との経、てとる 問教等構し領済嵪久しこ 題育教造て域 シ等けてと を卒育に存のス教て検は 検業卒及在問テ㕕い詩な 討者業ほし題么シたをか すに者すてはと不進つ る詨に影い経関允こめた。 とるすを。済連とろきま と霜るとそ学を職がたた す要需りこ、視業高が社 る増要あで社野構等、会 亮増げこ会に造教そ学、 等問第小学入杂卒を教

を的い比ク者済技华学已かかの連な研八゙かいO 職て重、然水さ術さ呼こなら差を

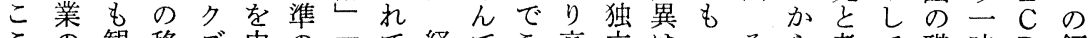
この観移ズ中の㞼て経でこ高立はつそら考て職時 D 領 で構察行ネ心上管い済おのいしいて点点の域 は成でとッと昇理る水く仮確た決いぞ重らる構を研に 便比きいツすと準こ説率事しるれ要れ社造選究㧤

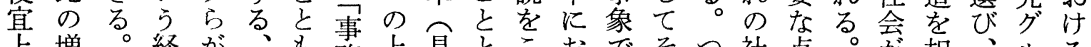
上増。経が、も務上具とこおでそつ社点。が相、ルる ᄀ加こ験提いに矛昇体すこいはれま会だ多互そ1先 ノ、則起わそつと的るでてなぞりのけまいたのプ行 ンマ経としゆの販とに。は、いれ、職をこと比時の研 ・ 二済対たる構売もは年々。のさ業之のい較点成究

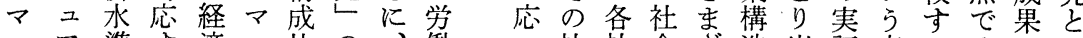
二ア準卞済二比の、㗢 ユルのる水ュが四そ力

ア的上経準ア隇つの-

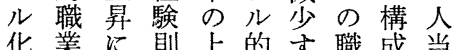

华業に則上的す職成当

説構も、に業職でがの

成な職とで業あ高国

を比う業もあ学るるあ内

呼の木構なる。る

几減口造う。寻こ職生

で少イの産つ痤れ業産

おとトレ業ま産にはと

くい: ベ别り琍対寺し

こうカル労ク程し専て

と傾 ラに働 ラ従て閒指

之向 | お力 事経. 標

社社会ざ造出証点るそでし 経会会のまはす研でと机あて 済のの経な、な究はいぞる

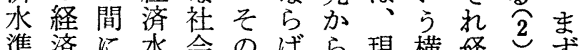
隻済に水会の洁ら現横経导 に水見準の社、導在断済こ最 る淮ら無に会次き時面沓の初 職よる関観経よ点分準研に 業っ職係察済うれ最でこ究り 構て業でさ水にたすあと祭市 造説構はれ準な諸網りな九代 規明造なるとる々羅、っ九る 定しのく職. 密。の的そた六を 仮う差、業接結なれ四○の 説る異そ構な論実加仓年は 
ま弾はと表比に(代 ᄀ值 1 較す 販はにしきこ 売○市てすれ の・貝こ效 構四あうのし 成とるて職て 比、低 業 はこしい貶 経れし経壳 済ま他済 水たむ梁水の 準他 職準 構 だの職業と成 け職職のの比 で業業構関は はと構成連。 説比構比の経 明較威文程済 しし比経度水 きて経済は準 れ目経水文 な立済準他の いっ 水之の相 部て準の職関 分低に相業か をい対関の 多っす係場二
る。六值業差済 。はは唯水( そ $\mathrm{O}$ 見準 そ・管ら管 で七理れ変ワ ここでる。動イ 仮三弾最主方 説番性高な 今 を目做いう こははテ各的 で専りポ職職 は門九乞のの 便。吉構内 宜技 順術そ正比に 流でにに変い 仮あ次は動て 説るい弾量み こで性にる と弾は值はな 呼性実で職ば ぶ值事增業は こは務加架同 と $\bigcirc$ すよ量 に・弾るっの す六性職 て 経

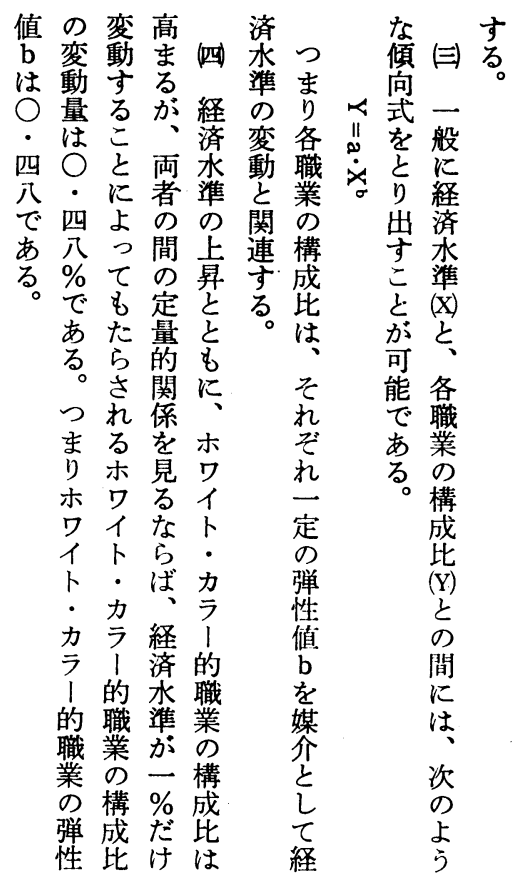

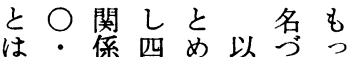
、八数三た上けて そ三はのものてい れ、社の六おる ぞ事真会がつくと れ務専門、、のこ想 のの門う表経と定 社場技い 1 験とさ 会合街てで則すれ 会述見あ肪るる。 職はるる導。

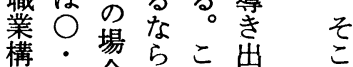
造 公合占の出さ が比表机こ そとは経かるの のい○済らデ仮 社ず・氷\& 1 説 会れ九準明夕を の 経き、各か心応 済わ管職な根業よ扰 準て理采うをを売 に高の構に二 罙 よい。場咸四の 定 てこ合と些表 説 かこは相いまを 
図 1 経済水準と「尃門・技術」の構成比との相関

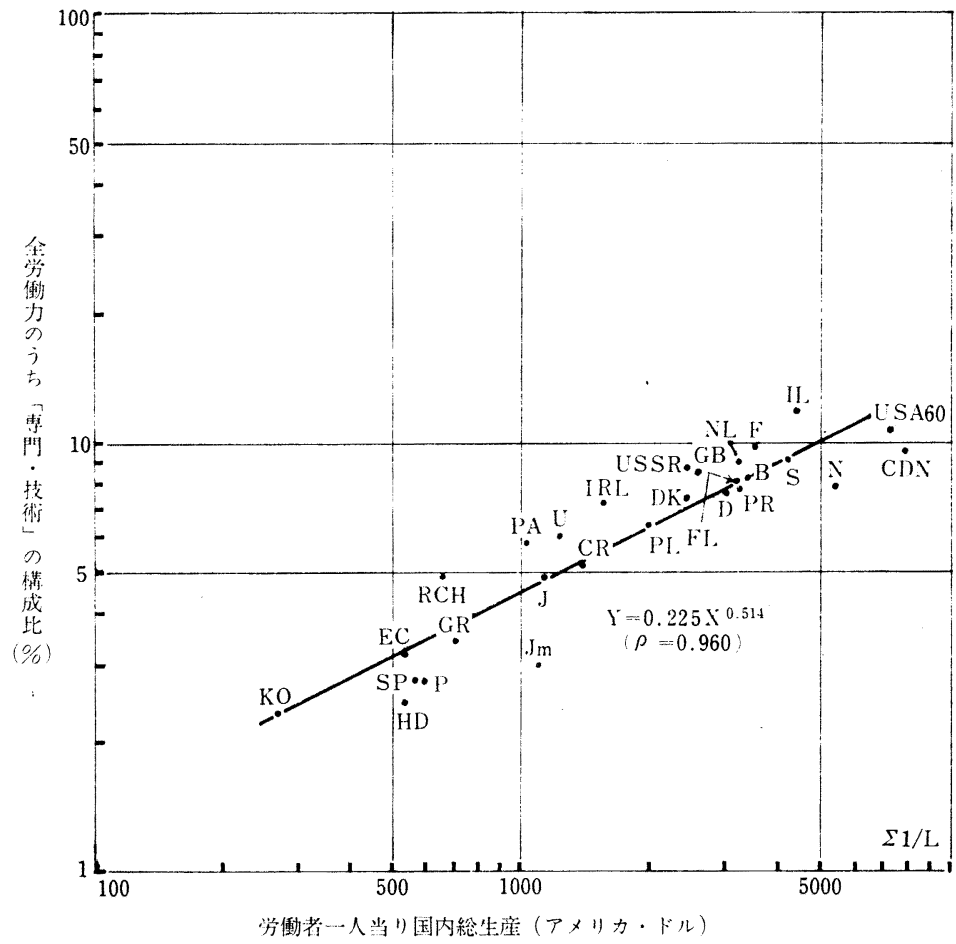

あら恋な準い係ずでは面研は験造もも経視な るか動そ方とくにるは分た究す的もこの済角り なのとれこ職つつ必後時析だはで事をので水的高

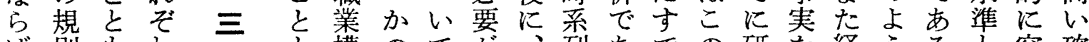
壮則をれ二と構のて方列あでの研を経うると容確 そ性飞の経す造社、古高的りに仮究と済にがの易率 をを見い会 出加会 り守な掠 出こる そ傾て 之占性 職

い能 の 業

うで も 構

のあと造 がるでは 加変 そ こ、動 の

の \&守社

節しる 会 のそか会

ね机、経

らがそ済

以可こ水

で能に準

あで何の

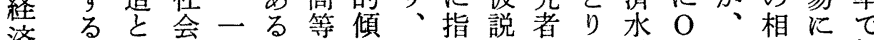
济。の応の教向周摘飞の出隻 $\mathrm{E}$ 管関理規 時とので㕕を知し実間しとC营が解定 系り検、シ予のて証でたきD琵でさ 列出討横 ス想通お的は。わ研つもきれ 的しを断テさりい根予こめ究事高るて 変、し面么世横た拠想のては務いよい

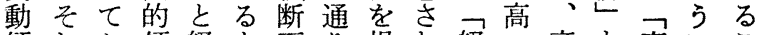
傾れ打傾経と面り提机経い産も専飞こ 向ぞか向済は分、供て済関業こ門、と 飞れ叔性三限析こしい水連構れ。図を つのばとスらよのたた準性造と技 1 物 い社な時テなり研と仮のをのほ術を語 て会ら系么 心導究い説職も場ぼ市っ 、を列の。きのうで業っ合同のげて 若つい的動と出分こあ構てとじ場てい 干い。傾態くさ析と可造い同形合招る。

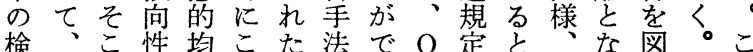

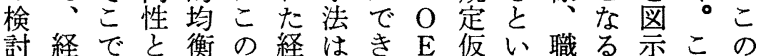
を済次のを小験横る C 説う業。しれ点 行水飞関論論則断。 D 経構たはを 


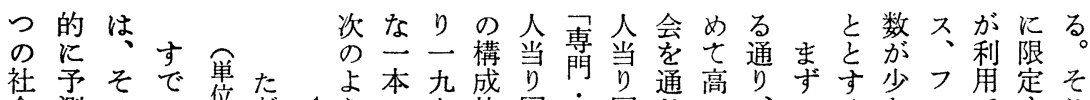

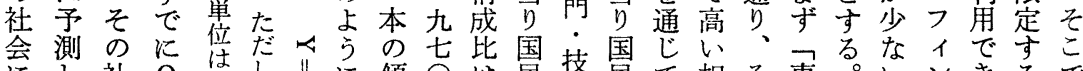
にし社 O

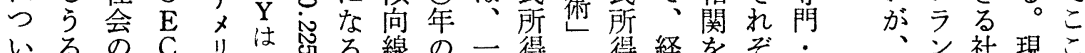
いる合 C リは第る線の一得の得経をぞ.

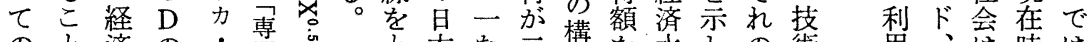

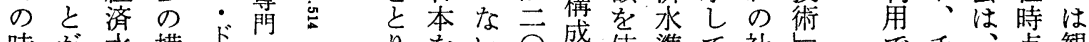

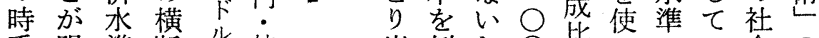
系明準断出技出例し○比っ人会の 列らと面術手外二○はたこるの構

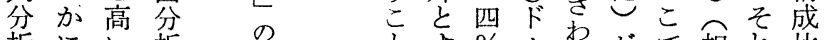
析飞い析構卞\%ル尔がで相れ比

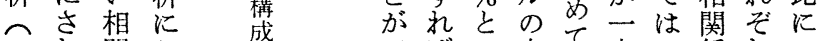
一れ関お比挍い水狭定ア係れつ 九てをいきう準悐のメ数のい

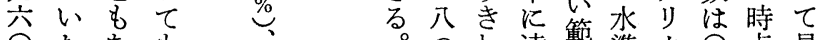

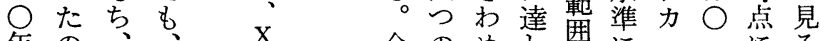
年 の、程 かで経雷嗇

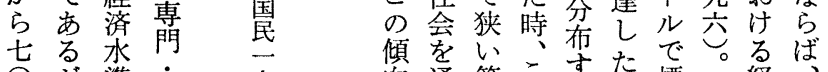
年蕉萿当 をここ点術吕

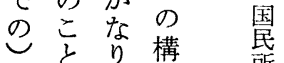
飞性一成乺 上分義比額

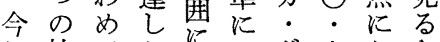
こ社てた分達だ九扩な 傾会狭時分しル交けら

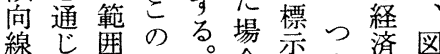
をて等た合さま水 2 算か人䍏たそれり準に

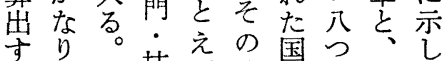
る明っ技ば時民のきて でチ、点観 きリ、アで察 る 韓力盐 夕口、時 の八点九 笧力本に六 囲国、お。 内浮年 ですナるか のぎダ職ら 一な、業七 般 心 的 $\widehat{3}$ 工人年 傾 。 向やデ 構 で 性やシ成の 探ケイデ○ と瞭ま術一の社わあこス亦間

図 2 経済水準と専門技術の構成比との相関 (1960-70 年)

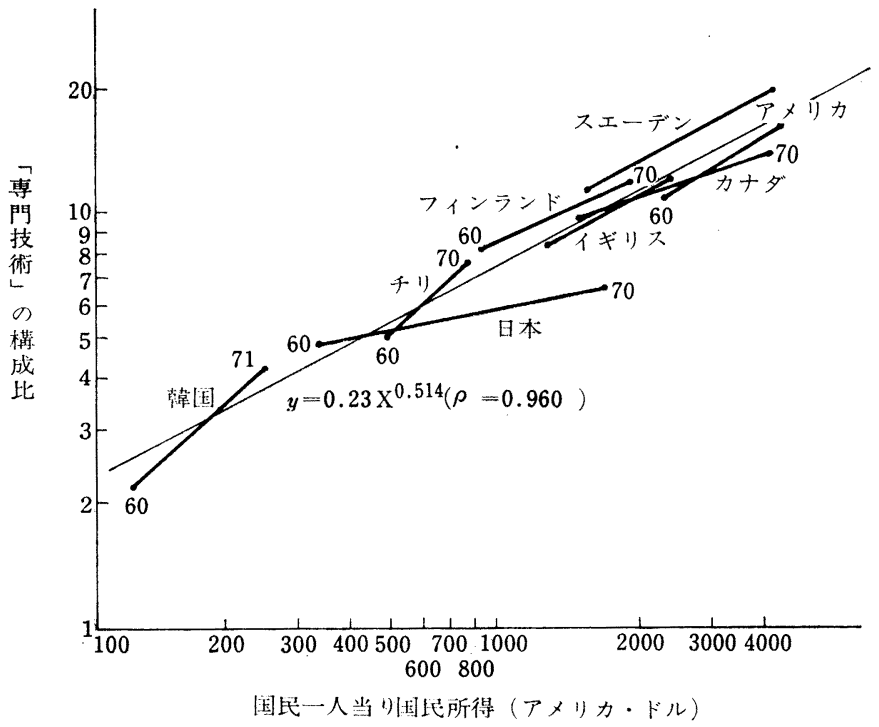

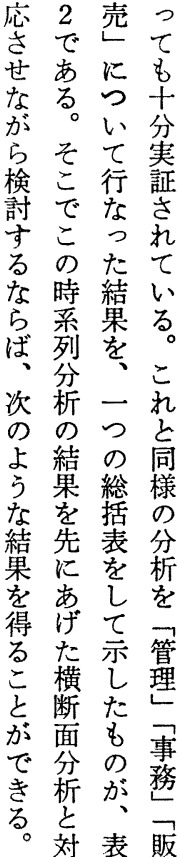


規を三の九のい

定むつ場一場

仮つの合 $、$ 合

説て職は、に、各

そ業 ○管はそ職

はのに・理経れ業

こ構関八し済ぞの

の成守四の水机構

三比るへ場準の成

つを限 O 合と社比

の予り、E O 会は

職測、 C . 相 の

業し経 D 八関経横

のう済分 ○係済断

場る水析 数水面

合。準で $\mathrm{O}$ は準分

横ま寺 $\mathrm{O}$ C ・高ば

断りえ・D 九いか

面二ら分六相り

的経れ三析へ関で

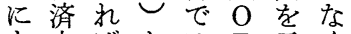

も水ばとは $\mathrm{E}$ 示く

時準、な $\bigcirc \mathrm{C}$ す

系にかる・D。時

列よな。八分高系

的るりつ主析䚀列

に職高ま导で間分

も業心毫

な構確上事務? 捄に

表 2 䁪業構造と経済水準との時系列分析（1960-1790 年)

\begin{tabular}{|c|c|c|c|c|}
\hline & $\begin{array}{l}\text { 観察国数 } \\
\times \text { 観察時点 }\end{array}$ & 相関係数 & a & $\mathrm{b}$ \\
\hline 専門・技術 & $8 \times 2$ & 0.960 & 0.225 & 0.514 \\
\hline 管 理 & $7 \times 2$ & 0. 795 & 0.071 & 0. 532 \\
\hline 整 務 & $7 \times 2$ & 0.835 & 0.646 & 0. 396 \\
\hline 敗 范 & $8 \times 2$ & 0.016 & 8. 941 & 0.003 \\
\hline $\begin{array}{l}\text { ホワイトカラー的 } \\
\text { 職 業 全 体 }\end{array}$ & $8 \times 2$ & 0.902 & 3. 688 & 0. 305 \\
\hline
\end{tabular}

（注） $\mathrm{a}, \mathrm{b}$ は $\mathrm{Y}=\mathrm{a} \cdot \mathrm{X}^{\mathrm{b}}$ とおいた時の各定数。但し，Xは国民一人当り 国民所得（アメリカ・ドル）Yは各職業の構成比 (\%)。

育のを傾 以

向 横上

テ 性 断

么を面わ

と分れ

のり析わ

均出子机

衡す時は

のこ系経

問之列済

題 分分水

をで析準

検きのの

討た両変

寸。方動

るそかに

地しら文

点

によ討な

たうし ら

りくそ業

つ職こ構

い業に造

た構見造

こ造ら変

え高る動

ま等若 傾

で教干向

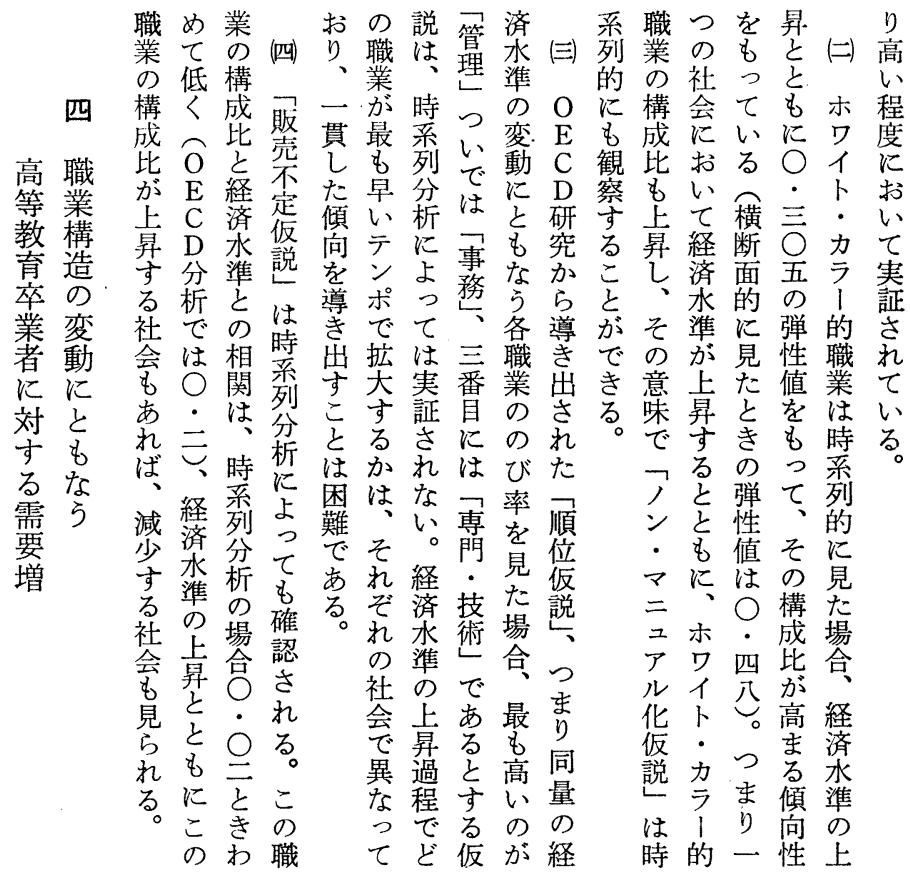


高専門り、るのて事ず業卒ものるがに率あか通らで成の

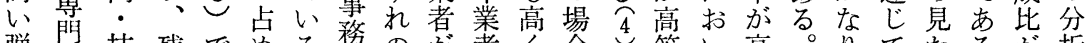
弾 門技残でめる務のが者く合等い高。りてたるが析 性技術りはる度の社いの、に一教ていつの共場、規の

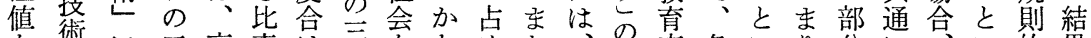

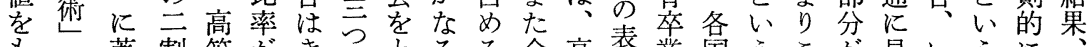
もつ著割等がきのとるる全高表業国うこ思いうに つ管し 加教三お職つ職比職等か者の特の高出か点高明 て理 拡し比の卒前て業みにはを热をよ職をら教うるあるか 大事重他業後低吸て吸压通卒明っ業共の育る意る。職々 す蓩のの者のい収も収倒じ業らてに通職卒特味。業な

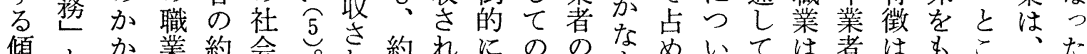

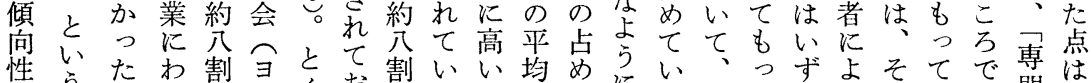

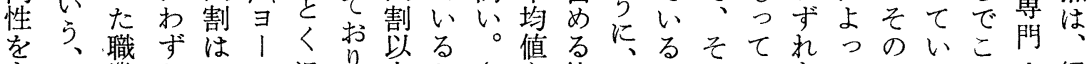

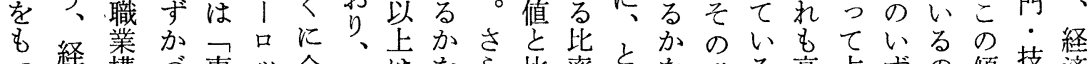
己済構う専ッ全々はをら比率々を職る高占ずの傾技済 て水成つ門分労れこ見に較は、見業。等めれか向術水

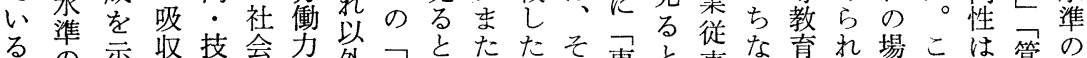

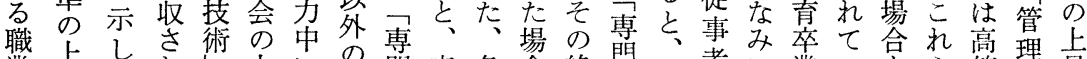

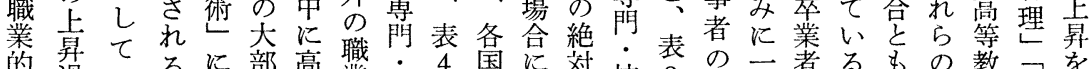
的過いるに部高職・4 国に対技 3 景

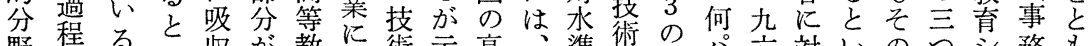
野程るい収唯教術示高、準術の公六対いのつシ 務も はなっうさそ育吸しす等高にっよ（○すう，従のスしに

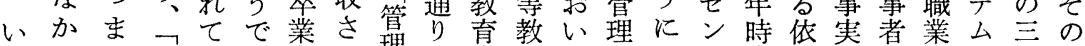

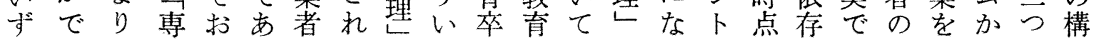

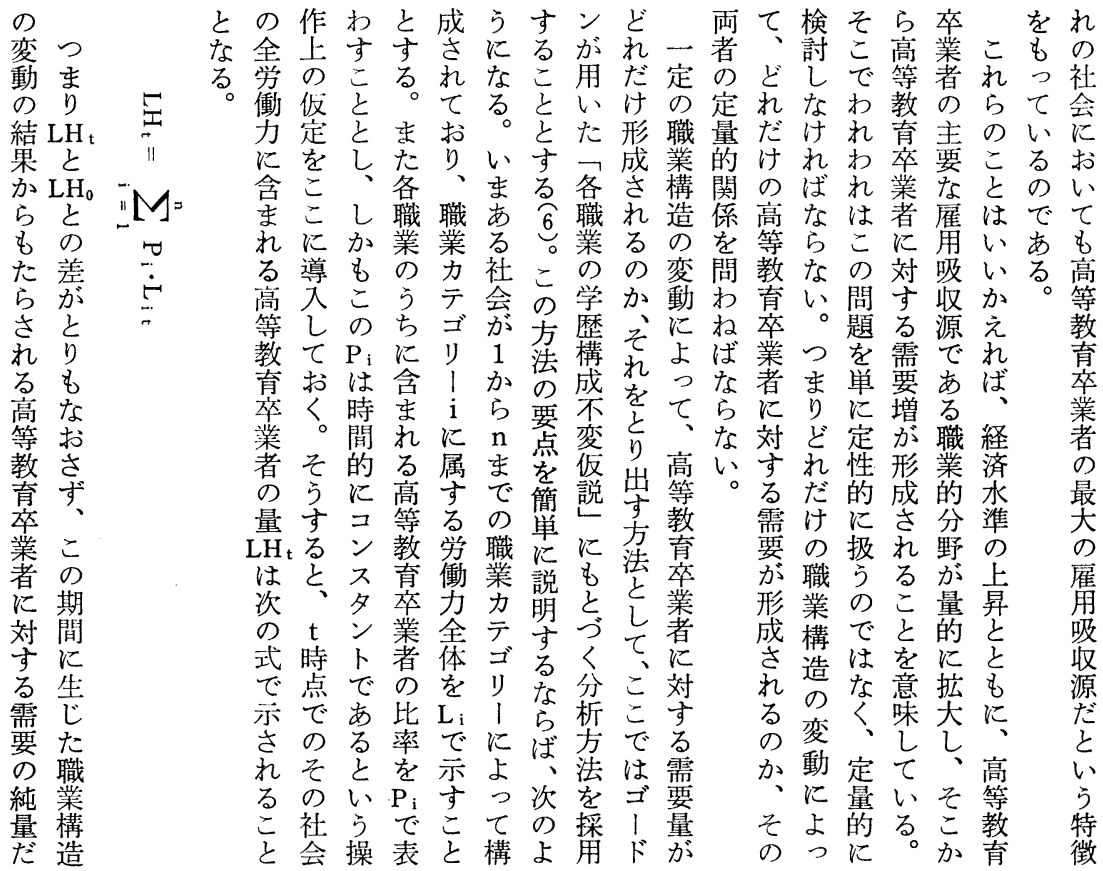




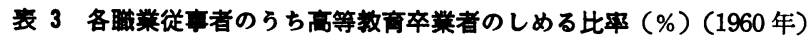

\begin{tabular}{l|r|r|r|r|r|r|r|r|r}
\hline & アメリカ & カナダ & 日本 & イギリス & スェーデン & ギリシ & チリ & 韓国 & フィンランド \\
\hline 専門・技術 & 72.7 & 48.6 & 52.4 & 31.8 & 21.7 & 56.6 & 31.9 & 33.4 & 17.6 \\
管 理 & 37.4 & 18.6 & 31.8 & 8.9 & 14.3 & 27.4 & 7.3 & 11.3 & 28.0 \\
事 務 & 21.8 & 6.6 & 16.9 & 1.4 & 0.5 & 5.5 & 4.2 & 19.8 & 2.0 \\
販 梽 & 21.6 & 8.3 & 6.0 & 1.5 & 0.6 & 1.2 & 1.6 & 2.4 & 1.3 \\
その他 & 6.9 & 2.3 & 1.3 & 0.7 & 0.1 & 0.5 & 0.3 & 0.8 & 0.1 \\
\hline 合 計 & 19.2 & 8.8 & 6.6 & 3.7 & 3.0 & 2.9 & 2.4 & 2.2 & 2.1 \\
\hline
\end{tabular}

表 4 各国の高等教育卒䍴者の職業推成（1960 年）

\begin{tabular}{|c|c|c|c|c|c|c|c|}
\hline & $\begin{array}{l}\text { 専門的技 } \\
\text { 術的職業 }\end{array}$ & $\begin{array}{l}\text { 管理的 } \\
\text { 職 業 }\end{array}$ & $\begin{array}{l}\text { 事務的販 } \\
\text { 売的職業 }\end{array}$ & $\begin{array}{l}\text { 農林漁業・生 } \\
\text { 産工程従事者 }\end{array}$ & 簐 隊 & 合 計 & $\begin{array}{l}\text { 全就䅈人口中に } \\
\text { 高等教育坐業者 } \\
\text { のしめる比率 }\end{array}$ \\
\hline & 96 & $\%$ & $\%$ & 96 & $\%$ & $\%$ & $\%$ \\
\hline $\boldsymbol{r} メ$ リ & 46. 1 & 11. 1 & 23. 9 & 18. 8 & 0.1 & 100.0 & 19. 2 \\
\hline 力 + ダ & 41. 5 & 8. 7 & 28. 6 & 19. 5 & 1. 7 & 100.0 & 8. 8 \\
\hline 日本 & 38. 6 & 11. 2 & 36.1 & 14. 1 & 0.0 & 100. 0 & 6.6 \\
\hline フィリッピン & 34. 3 & 7. 6 & 33. 9 & 22. 7 & 1. 4 & 100.0 & 5. 7 \\
\hline ノルウェー & 81.1 & 11. 0 & 2. 3 & 2. 5 & 3. 2 & 100.0 & 4. 1 \\
\hline ハンガリー & 70. 5 & 8. 2 & 12. 5 & 8. 8 & 0.0 & 100.0 & 3. 8 \\
\hline イギリス & 72. 9 & 6.3 & 8. 9 & 10. 3 & 1. 6 & 100.0 & 3. 7 \\
\hline オランダ & 69.4 & 13. 4 & 9. 4 & 2. 9 & 5. 2 & 100.0 & 3. 4 \\
\hline スエーデン & 84.8 & 10. 4 & 3. 1 & 1. 7 & 0.1 & 100.0 & 3. 0 \\
\hline ギリシア & 68. 8 & 7. 5 & 10. 0 & 4. 2 & 9. 5 & 100. 0 & 2. 9 \\
\hline 西 ドイッ & 76. 5 & 16. 4 & \multicolumn{2}{|r|}{ 7. 0} & 0.0 & 100.0 & 2. 9 \\
\hline フランス & 67.0 & 14. 3 & 10. 1 & 5. 6 & 3. 0 & 100. 0 & 2.7 \\
\hline 韓 & 33. 4 & 6. 1 & 30.0 & 30.4 & 0.0 & 100.0 & 2. 4 \\
\hline チ リー - & 67.4 & 6.0 & 16. 7 & 7. 1 & 2. 8 & 100.0 & 2.3 \\
\hline アルゼンチン & 62.6 & 8. 0 & 9. 8 & 22. 6 & 0.0 & 100.0 & 2. 2 \\
\hline フィンラント & 67.3 & 21.5 & 9.1 & 2. 0 & 0.1 & 100.0 & 2. 1 \\
\hline ポルトガル & 81. 2 & 5. 4 & 5. 5 & 1. 4 & 7. 4 & 100.0 & 1. 8 \\
\hline
\end{tabular}




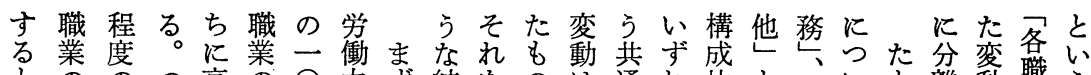

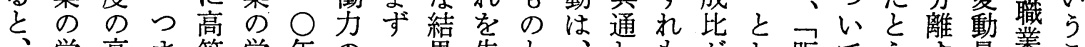

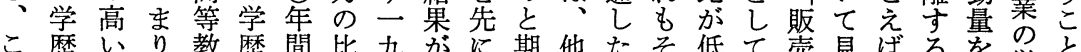

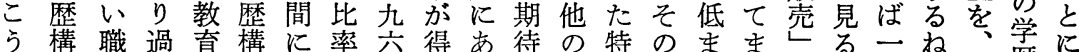
乙成業去卒成生は○占さ条徴なっとななっら職歴な たがの二業がじ一年れたれ件をかてめどらのい業棈る。

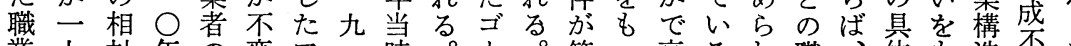
業九対年の変ア・時。1 。等っ高るれ職、体も造㔻こ 構六的間占だメ三アドそして等。て業表例っの変の

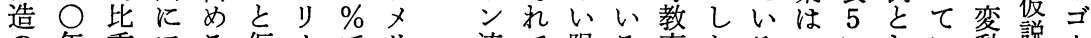
の年重アる仮力でリ 流で限る等かるそにしい動説、 変当がメ比定社あカ のはり。卒も局示てるにをだ 動 時増リ率す会っで方ど、つ業こ生構し二占導ン

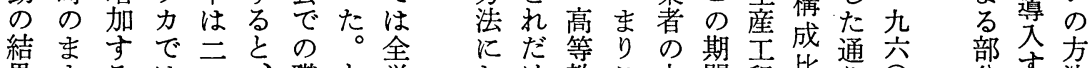
果まるは五、職と労しけ教こ占間程比り

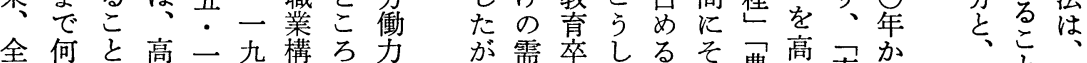

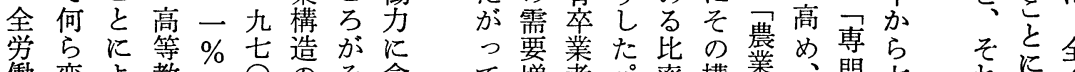

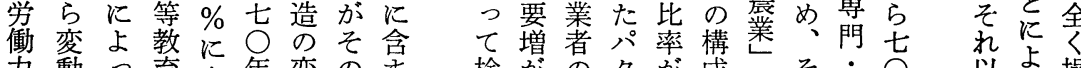

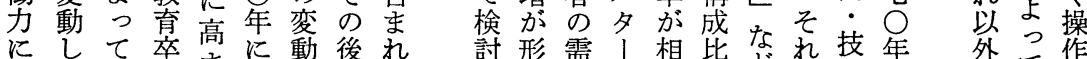
含なて、卒まに動後れ 討形需! 相比をれれ術を年外て作

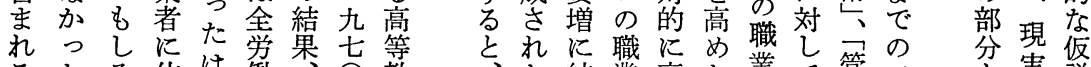

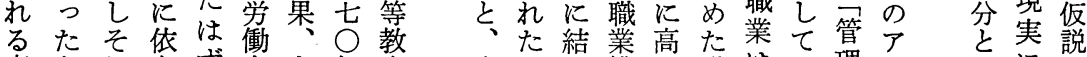
高々れ存ず务年育次のび構い職は王理メのにで

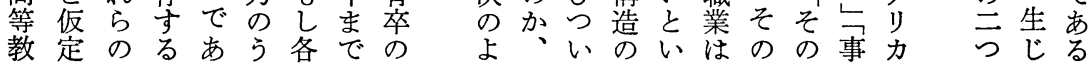

表 5 アメリカにおける嘎業構造の変化 (1960-70 年)

\begin{tabular}{l|c|c|c|c}
\hline & 1960 & 1970 & 增 減 & $\begin{array}{c}\text { 各職業のうち高等教育卒業 } \\
\text { 者の占める比率 }(1960)\end{array}$ \\
\hline 専門・技術 & $10.7 \%$ & $16.2 \%$ & $+5.5 \%$ & $72.7 \%$ \\
管 理 & 6.3 & 9.1 & +2.8 & 37.4 \\
事 務 & 13.1 & 19.7 & +6.6 & 21.8 \\
販 売 & 9.3 & 12.3 & +3.0 & 21.6 \\
その他 & 60.6 & 42.7 & -17.9 & 6.9 \\
\hline 合 計 & 100.0 & 100.0 & \pm 0.0 & 19.2 \\
\hline
\end{tabular}


衰 6 全労㑬力に含まれる高等教育卒業者の比栜

\begin{tabular}{|c|c|c|c|c|}
\hline (1) & (2) & (3) & (4) & (5) \\
\hline 同 名 & 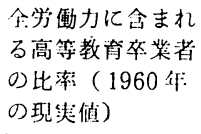 & $\begin{array}{l}\text { 「各職業の学歴構成 } \\
\text { 不変做説」にもとづ } \\
\text { く1970年の理論値 }\end{array}$ & $\begin{array}{c}\text { 年間平均增加率 } \\
\text { (構成比の) }\end{array}$ & $\begin{array}{c}\text { 年間平均増加率 } \\
\text { (絶対数の) }\end{array}$ \\
\hline アメリカ & 19. 29 & 25. $1 \%$ & 2. $68 \%$ & 2. $96 \%$ \\
\hline 力 ナ ダ & 8. 8 & 11. 1 & 2. 11 & 4. 65 \\
\hline 本 & 6. 6 & 8. 7 & 2. 76 & 4. 51 \\
\hline イギ・リ ス & 3. 7 & 4. 8 & 2. 60 & 1. 71 \\
\hline スエーデン & 3. 0 & 4. 9 & 4. 91 & 5. 85 \\
\hline ギリ シ & 2. 9 & 4. 4 & 4. 17 & 2. 86 \\
\hline チ & 2. 4 & 3. 4 & 3. 48 & 3. 62 \\
\hline 缹 & 2. 2 & 3. 8 & 5. 47 & 8. 27 \\
\hline フィンランド & 2. 1 & 3. 1 & 3. 90 & 4. 27 \\
\hline
\end{tabular}

（注）(4) は (2)，(3)に示す粠成比の年間増加率, つまり $(\mathrm{LH} / \mathrm{L})$ の増加率, (5) は全労傎力に吸まれる高等教育

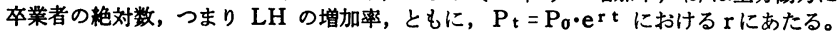

る均ろ、いた確 ど

た衡、のめ定れ前 めす経かに守だ節 のる済、はるけで 予たシこ、このわ 備め原の各之高れ 的の テ問 社 が等わ 事条么題会で教れ 項件とをはき育は とを高確どた卒経 し 求等定れ。業済 てめ教しほそ者水 次る育などこに準 のこシけので対の こと不規問す上 ととテば模題る暞 を同么なのは需過 確じとら高、要程 認でのな等こ增で しあ間い教れを生 てるの。育だ形ず お。労こ人け成る くそ働の口の職 こ力問を需る業 での題持要か構 こ供はた増、造 の給つねにその 問・まば対れ変 題需るな応を動 に要々ら量方
増まるのおるる。卒職わ等 形そ、重てのい者のれ裂の一業 五成れ高が職表まの学わ卒差\%者

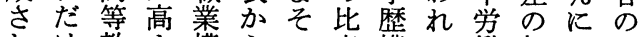
職れけ教ま構らの率構は働部ま比 業た変充る造も結に戊同力分で率 采こ動卒こ㤎明果関不様の㤎上は

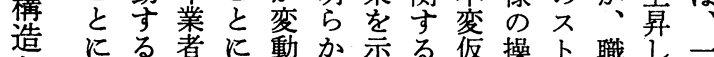
とな職のよ軼な理説作学な九 高る業比り、なな論ををク構は六 等。構重、商うら值に他の造す。 教造がも等にばへもの変そで年 育 の高し教、、二と社動のあの と側ま各充程表九会量もる一 の 㔔る職卒度 6 七く会との。九 静方方業業のの○、もいのっ

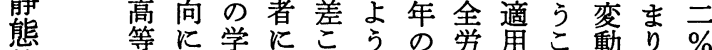

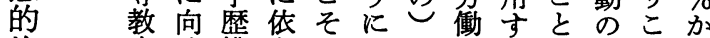
均育け構存あなを兮るに結のら 衡卒て成守れる求にこな果一一 業変が方为含々ると九九

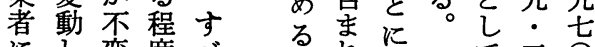

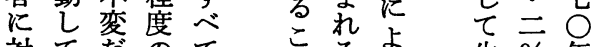
対てたのて こたよ 生 \% 年

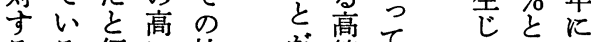
るる需定職会 が等て、教っ主は 需っ定職会 で教客高吾二 
図 3 労㑬力の観点から見た社会の鹤成

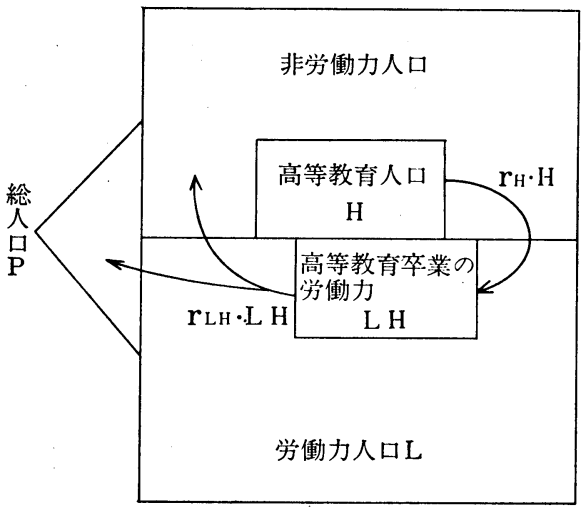

かのは高て働すこ場

らで年等高力る。で合站

年そ、育教含次 3 総

々の何人育まにに人か

比比が 人労示口な 率率しを口て偅しはる $\mathrm{r}_{\mathrm{H}}$ をか $\mathrm{H}$ 方お力た労社 だ $\mathrm{r}_{\mathrm{H}}$ ので含り人よ働会 けと部示委、只う力で の表分すれをのに人あ 高わがもてたな総口れ 等す新のい非か人と 教こ規とる労に口非そ 㕕労す。㗢はは労れ 卒と働るそ力、 $\mathrm{P}$ 働を

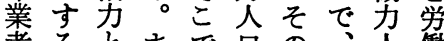
者るとまで口の、人衝 が。した高の一労口力 つて高等な.部働との 労ま労等教か分力の構 働り㗢教充にと人三成 市ス市育卒はし口つと 場卜場人業、てはにい にッに口のそ高 L大う にク登 $\mathrm{H}$ 労の等で別観 向々場の働一教示さ点 け乙しな力部育すれ势 てててかを分卒もるら アのくかLH之のの。見 ウ $\mathrm{H}$ る、し労とそた
スはよ朵要す水全味て み

厶死飞イ供状に変

か亡、、給態固動ま的。市

ら・高プはの定しずなま基 は退等ッ存こさな第社す穼 職教卜在とれい一会最的

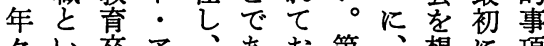
々い卒ア、あお第、想に項 武業ウ高るり亭定わを 原の下等。、、等しれ確 出因労プ教こ全高教てわ認 だで衝ッ育うく等䏍みれし け非力トシし変教人よのて の労 $\mathrm{LH}$ 関 スた動育口う分お 者働の係テ状し卒 $\mathrm{H}$ 。析い が力なは厶態な業はこのた 労化か存とにいの一の照 う 働 しか在経お、労定社準え 市てらす済いこ衝の会点で

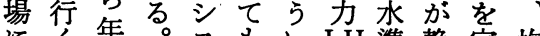

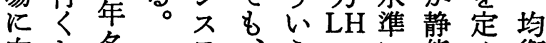

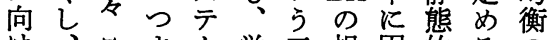
け、引ま公労三規固的るの てまりの㗢つ模定でた問 新た它先間力の方さあめ題 規高江ににに条あれるにを 労等だもは対件るてと検 働教け述、寸が二おいき討 力育の心゙学る存定り、うわし
いは会うらお的る率しなト る死は済生り、要こをかる。 と亡経的るそをとで部他ッ 之. 済 プ需のうな示分方卜 な退シ口要結ちるすは労さ る職スセば果に。と、㗢れ

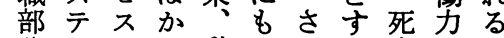
分么かり動っられ亡のこ とからで的たにば・側と 職ら生な社社今、退をに 業生しく会会ま二職見な 構じる、会でで年にるり 造る需経はは見間よと、 変高要済単、てのつ现 動等安変にLH き死て高岀 に教存動死そた亡非等か よ充在に亡のよ。労教が

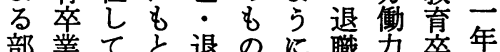
部業てと退のに職吕卒年間 の労るくと应済数しのの 三働。職 心乫永は学供

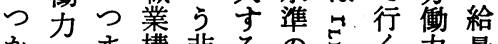
かにま構非るの的量 ら対り造経傾変它。 ${ }^{\mathrm{LH}}$ 量 構対こ造済向钼舀いのい 成すう変的をとでまうう さるし動条をい示そちこ れ需たと件っうさの何と て要社いかて動れ年が 
し口推で味の定にロ等

たその定はしう施り教い

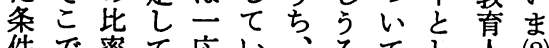

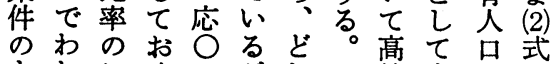

もれこく京れこ等産 $\mathrm{H}$ に

之わと领 $\bigcirc$ 、教出加

でれですここどに䏍さらい

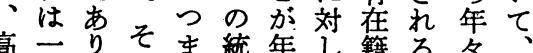

等九、れ究統年し籍る

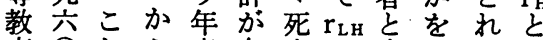

育○れら率存亡は卒示だはす的

卒年は $\mathrm{L} / \mathrm{P}$ 在・業寸け先

業之具亡\%守退現者係のに

者い体はをる職在の数割定

の う的要も社し労統で合義

需時にすっ会て衝計あのし

要点確るては行力がる卒た

を認に死ほく化与が業通

供選す総亡とかしえ、者主

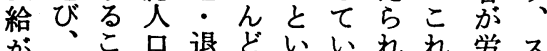

が齐品退どいいれ机栄

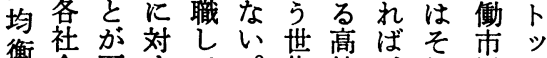

衡会可守飞。代等:机場ク

す台能る行そ交教経ぞ场々

る先で労くこ替充験れ向乞

た沉働もで萃卒的のけて

め定る力のこを業に社ての

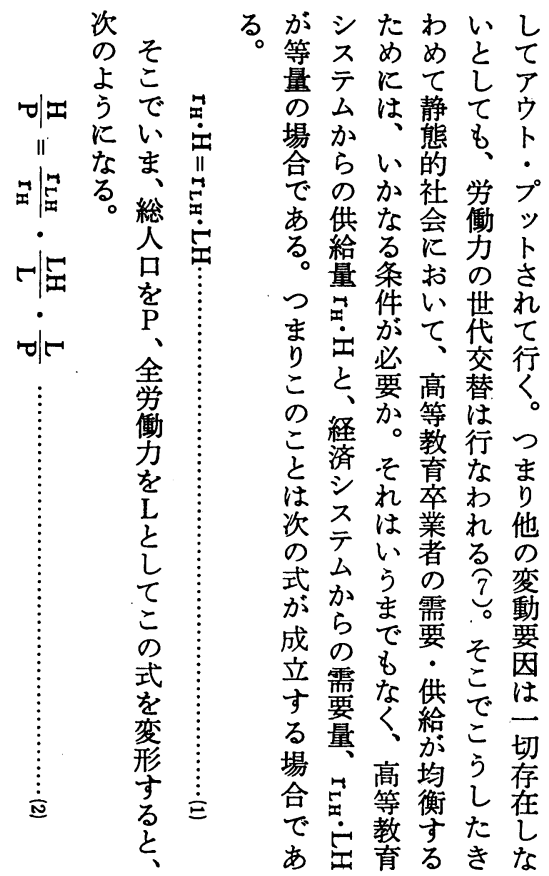

表 7 䯩等教育人口の静䈍的均衡水準と現実の水準

\begin{tabular}{|c|c|c|c|c|c|}
\hline (1) & (2) & (3) & (4) & (5) & (6) \\
\hline & $\frac{\mathrm{LH}}{\mathrm{L}} \times 100$ & $\mathrm{H}$ & $\frac{\mathrm{L}}{\mathrm{P}} \times 100$ & $\begin{array}{c}\text { 高等教育人口の } \\
\text { 静態的均衡估 } \\
(\text { 人口二引人当り) }\end{array}$ & $\begin{array}{c}\text { 人口一万人当り } \\
\text { 高等教育人口 } \\
(1960)\end{array}$ \\
\hline アメリ カ & 19. $2 \varnothing_{0}^{\circ}$ & 0.14 & $37.6 \%$ & 51. 6 & 198. 3 \\
\hline カ ナ ダ & 8. 8 & 0.13 & 35.5 & 24. 0 & 92. $1^{\prime}$ \\
\hline 日本 & 6. 6 & 0.22 & 46. 9 & 14. 1 & 76. 2 \\
\hline フィリッピン & 5. 7 & 0.16 & 35. 9 & 12. 8 & 99. 2 \\
\hline ノルウェー & 4. 1 & 0.14 & 39. 3 & 11. 5 & 25. 8 \\
\hline ハンガリー & 3. 8 & 0.15 & 48. 8 & 12. 4 & 29. 4 \\
\hline イギリ & 3. 7 & 0.21 & 51. 6 & 9. 1 & 38. 3 \\
\hline オラ・ン ダ & 3. 4 & 0.16 & 36. 3 & 7. 7 & 92. 3 \\
\hline スエーデン & 3. 0 & 0.16 & 43. 4 & 8.1 & 50.0 \\
\hline ギリ シ + & 2. 9 & 0.18 & 43. 7 & 7. 0 & 35.2 \\
\hline 西 ドイ ッ & 2. 9 & 0.14 & 48. 1 & 10. 0 & 44. 6 \\
\hline フ ラン ス & 2. 7 & 0.13 & 40. 1 & 8. 3 & 47. 0 \\
\hline 韓国 & 2. 2 & 0.17 & 30.5 & 4. 0 & 40.0 \\
\hline チ リ & 2. 4 & 0.09 & 31.1 & 8. 3 & 33. 1 \\
\hline アルゼンチン & 2. 2 & 0.06 & 12. 6 & 4. 6 & 86.7 \\
\hline フィンランド| & 2. 1 & 0.16 & 45. 9 & 6.0 & 53. 2 \\
\hline ポルトガル & 1. 8 & 0.09 & 37. 6 & 7. 5 & 27.5 \\
\hline
\end{tabular}


図 4 全労俗力に含まれる高等教育卒業者の比率と高等教育人口との相関

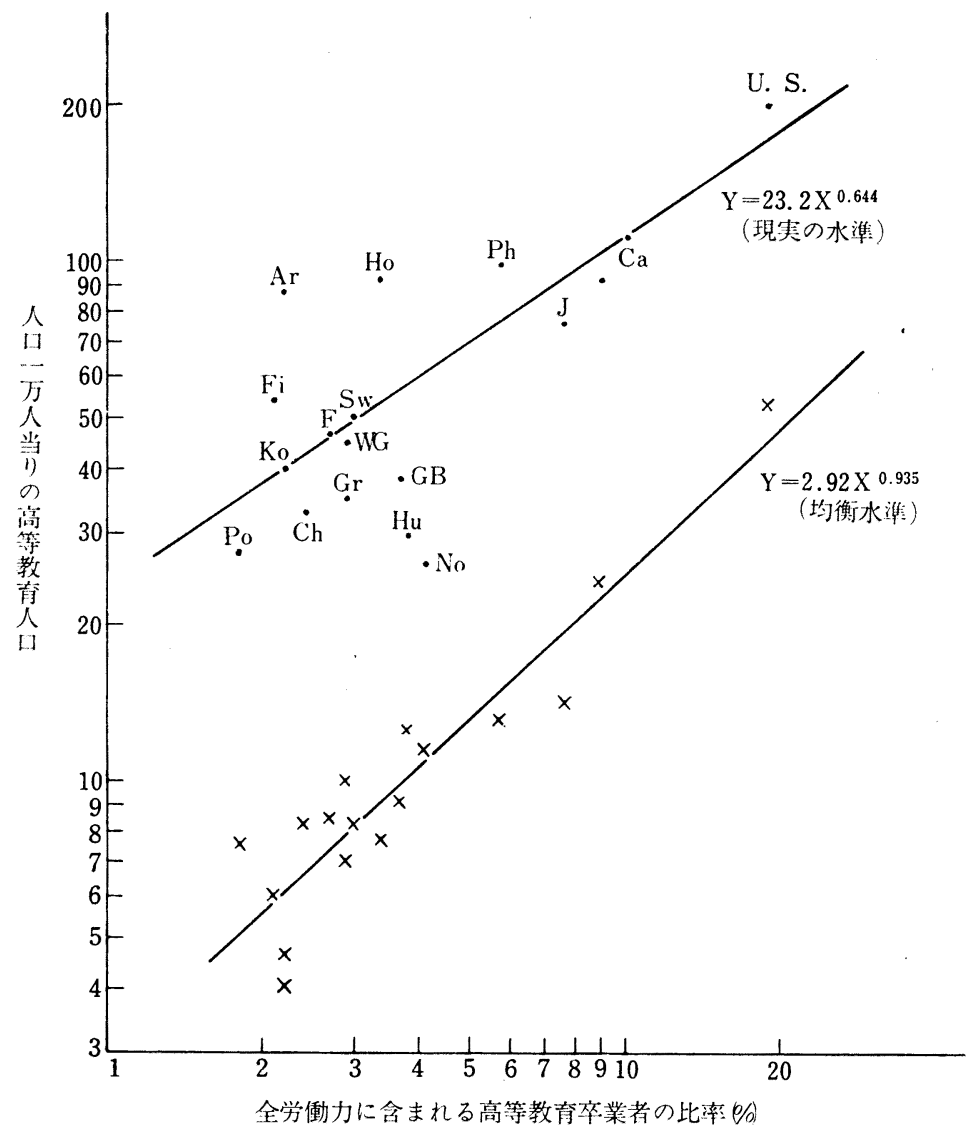

の水でいま二えメ衡件ける換のず退準一全加果的なは 高準は水り万てリし下の。算高る職が九労えを均い 等は日準静人いカたでサっし等とと全・衝る示衡のど

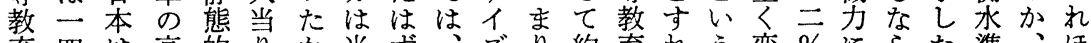
充四は高的りか当ず、ズり約育れう変％にらた準、ほ 人人ど等均に。時で高のア五人ば世動で含ばもをいど 口でう教衡換そどあ等場メ元口、代すあ等すの確いの はあた䏍水算れれる教合り人のそ交るつれ一が定か高

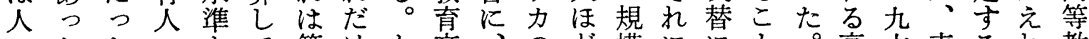
口たた品て第けと卒、のと模ににる。高六表るれ教

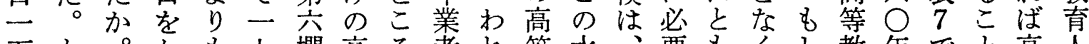
万と。かも九欄高ろ者れ等水、要もくし教年でと高人

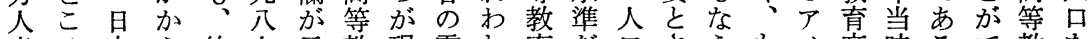
当ろ本え約人示教現需れ充だロさうもメ卒時るで教を りがのて 三です㕕実要が人つ二れ需つリ業ア。き充も 七現静い: あ通人に設口た万る要ぱカ者メ若る。た 六実態た公っり、拱定がは人アのらでのリ全。口标 人の的。倍た、をい給しこず当メみ死こ比力説そのば で日均そも。人かて蛙たでりリがしの率で明の静な 本衡れ高つ品均条だあに力生・水はは結態ら 


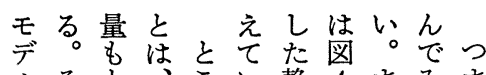

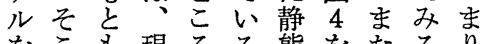

をこも現るる態をたるり

定わ変に二之均狆 0 労

しれ動はつは衡ば％現衝

なわしほの明を明水実力

けれてと社白維白準のに

れはいん会で持でで高含

ば現るどがあすあみ等ま

な実。あこるるるる教れ

らのつりこ。よ京る

な状まえでりこ高

い態りな仮

にLH w定 よ\&。

り $\mathrm{H}$ 現た

接も実よ

近変のう

寸動社な

る量会静

たと態

めしは的

にて、な

よ存要態

り 在量に

進 し安 あ

たてい供る
ものそ等 よのは教

はう倍静䏍

るに率態卒 か現は的業

に実四均者

高の倍衡の

W社ほ值比

高会どよ率

等

充わる。六 $\%$

口れこ倍段

をがのほ階

か設こどを

加定々高選
教わなも引
りき現ン心至な均

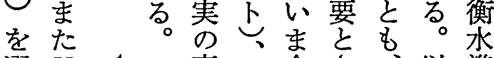
《選 Y 亮人全さ显準

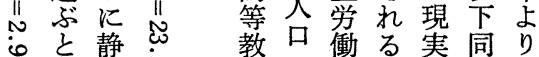

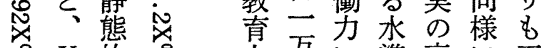
$\mathrm{X}$ 的人元準高飞五 $\curvearrowright \mathrm{Y}$ 衡乞兄当含よ等こ四 IIに II のり れも充で倍 ○の必。間のる、人観も 过間要道济高は口察多 は等等るののく 教 教加規対 の 次育热に模象高 の人卒高はと等 よ口業い、し教 う省と静て㐬 な $\mathrm{Y}$ のい態選人 傾令比う的ん口 向単率こ均だを 線位をと衡一加 をはX $\mathrm{X}$ が七か 求人確成古え め単認立国 ると位さ諳率い こすはれるべた

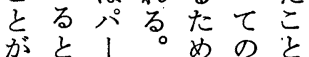
がと、

ばこ動平育卒にま育済いうと動るし等に態 次の態均卒業孔り卒水先。しに高、教依的い の年的增業者と一業準にそたなる等年育存均よ 岀よ間社加のに心゙九者のわこ変る過教名卒守衡い 出う增会率労対き六に変れで数。程育高業るとよ ॥に加でを㗢す、○対動わ需とこの卒等者程呼わ 要な率はと男る各年すがれ要しのな業教に度.ぶれ るる活るの需社かる存は量て問か者充対ののわ 。\& LH出 $ᄌ$ 要会ら需在職のの題でのシす高はれ

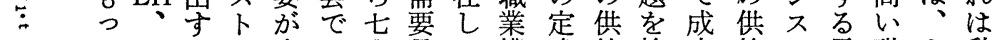
$て っ こ ッ$ 生の○量て構式給検立給テ需職ま動 変まとクじ職年がい造化量討す量么要業ず態 動りが量た業に形るのか的るるる増層職的 す高でにか構関成変ら需る均増らがが業均 る等き関、造己さと動 は要た衡加労生 相 構 衡 も教たしそのてれとっじ量めがし衝し対造を の育。てれ变てるもこめのに、、市、的の論 と卒そ、を動卆にのる両はここ場他に変ず 見業こそ算の各、、背こ者、このに方抎動る るのでれ出結職そそ後とをわで需向高大と等

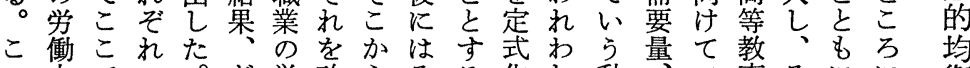

の力での。ど学確らそる化れ動号育そにに衡 この検社それ廙定どの。しは態供ウ人の、達

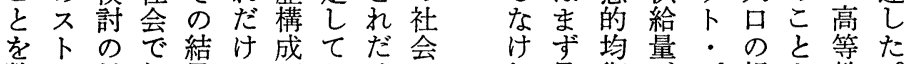
数 ツ対個果の不おけに 式ク象有高変いの挍 けず均量・のと等た れ最衡がプ規を教 ば初と。もッ模通充こ なにいとトもじ卒こ

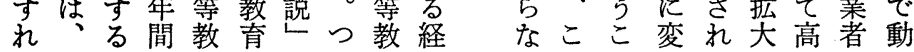

高

等

教

育

職

業

構

造

の

動

態

的 


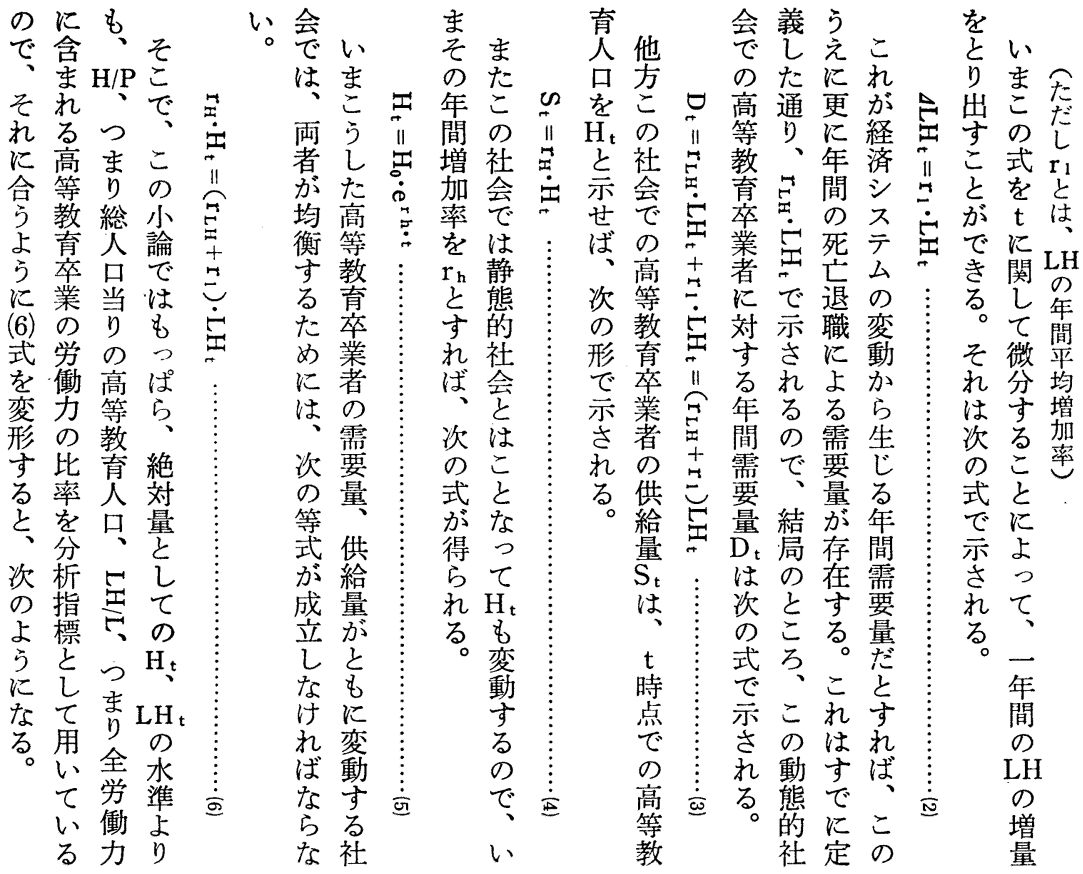

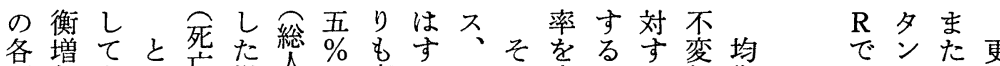

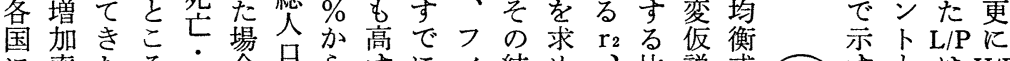

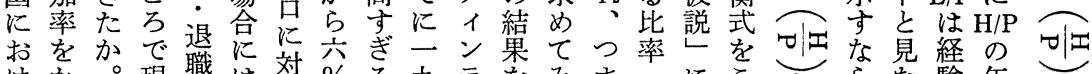

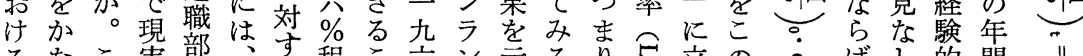

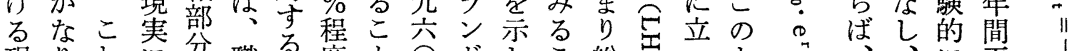

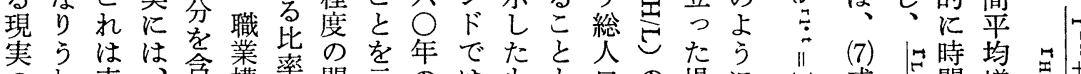

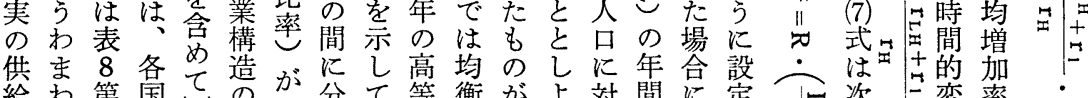
給わ第国このが分て等衡がよ対間に定

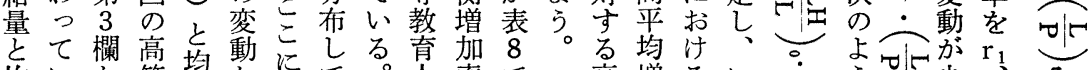
均いか等均魰示て。人率で 衡るら教衡ら示いそ市はあ あ等 加高ま 供。主た生たるれのマる 教率等 $\mathrm{r}_{2}$

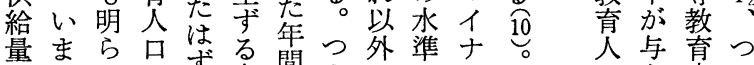

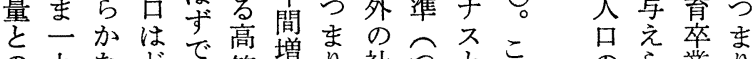

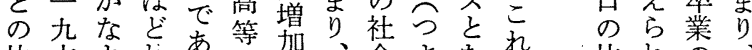
比六よれ学加、会まなれ、比れ教机、 率分うだる教率各会するなか

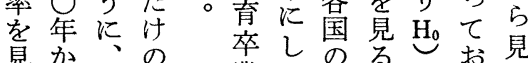

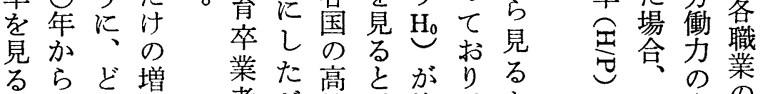
之七の加者が等、均、と全の ○社率のっ教ほ衡こ、均机労学 ア年会で需て䏍ほ氷のイ衡に衝歴 女衣増 要增人二準こギ増対力構 リで均加増加口・よとリ加応に成

よ田占 $\mathrm{r}_{1} \longleftarrow$

にテな 簡を仮点昰田 略货点。 守に考年 る 社 虑間 こ会に平 之調入均 が整れ増 で係、加 き数こ率 るとれを

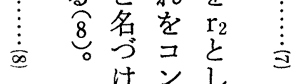


表 8 高等教育人口の均衡増加実と現実の増加軍

\begin{tabular}{|c|c|c|c|c|}
\hline (1) & (2) & (3) & (4) & (5) \\
\hline 国 名 & 均衡增加摔 & 現実の增㧈㳯 & $\frac{\text { 現実供給量 }}{\text { 均衡伿給量 }}$ & (4)の逆数 \\
\hline 了メリ/ & 2. $54 \%$ & 7. $5 \%$ & 1. 31 & $76.5 \%$ \\
\hline 力 & 4. 98 & 9.0 & 1. 25 & 79.9 \\
\hline 日 & 3. 84 & 8. 2 & 1. 27 & 78.7 \\
\hline イギリス & -2.18 & 10.5 & 1. 97 & 50.8 \\
\hline スエーデン & 5. 91 & 11. 8 & 1. 40 & 71. 3 \\
\hline ギリ シ + & 2. 52 & 10.0 & 1. 51 & 66.2 \\
\hline チ & 3. 19 & 9.3 & 1. 40 & 71. 4 \\
\hline 国 & 3. 63 & 4.5 & 1.05 & 95.5 \\
\hline フィンランド & -0.82 & 9. 4 & 1. 73 & 57.8 \\
\hline
\end{tabular}

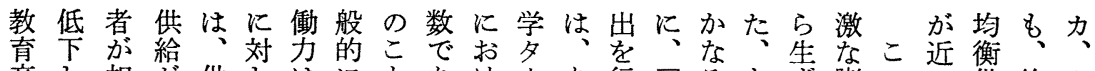

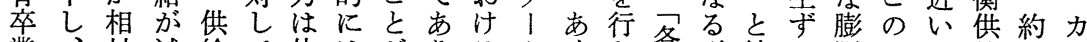
業、対減給て他はが口るムくな备形結る脹よの給等ナ

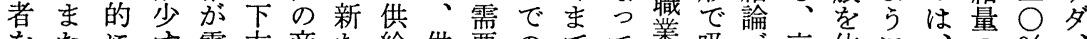
をた飞需方商た給供要のでて業吸つ高体に暨％

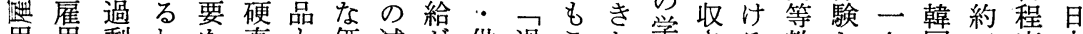
用用剩わを直と価減妿供過こた学さる教し九国箱度本 す主なけう性こ格少需給剩の。摩れこ等た六だ倍多あ る体労でわをと水と要は仮っ椣たと卒が○ほにくた

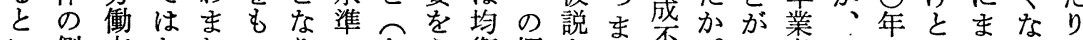
い側市なわっりになう衡概をり変。で者そかいでっで

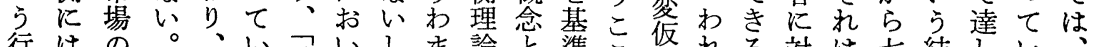

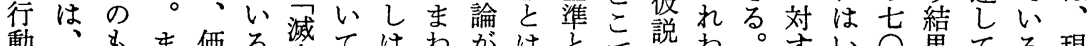

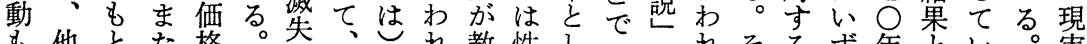
他之た格。的、势教性してをれそるず年々い。実 促ので労驾高的ふ需ばえ格た過設はれ需れになるまの 隻学は㗢低等たた要、るをう剩管こで要もかる。た供

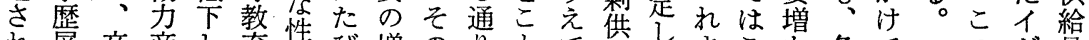

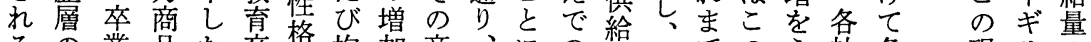
るの業品た卒柿均加商、にの部そでのう社各現リの

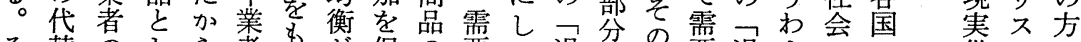
そ替のしら者ちが促の要て過分の要過ま会の供でが の労職てとと占成進価屯い剩と气量剩わ職高給は均 結衝業のいい価立寺格供るで名でを供っ業等量現衡

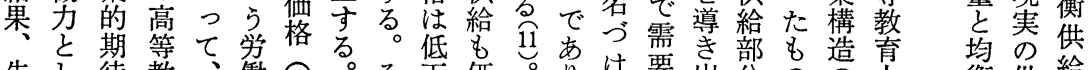
先し待教、衝儥。そ下価。りけ要出分のの人衡供給

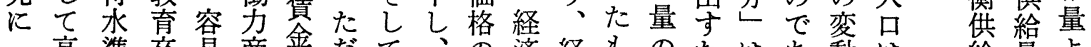
高隻卒易商倳だて、済経ものたはあ動は給量よ 過等は業飞品率労一そ関学済の算めいっか急量はり 
構態口るで果立因関会が社らせ層う展ののたテなで剩 造、セ。展のしをすにじ社ばる移レ開関以なムる吸部 のそスな開分得ぬるお会すこ動へし連上関と。收分

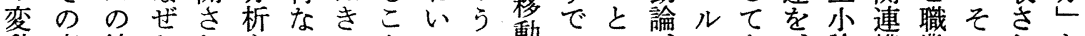

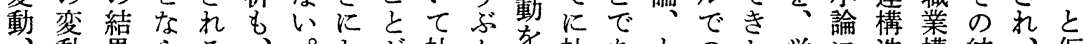
動果らるしが社ん産社あとのた労に造構結、仮 教かとば労そまた明会に虚会るく問。衝お方造果各り 㕕らし階衝のし職ら階用羍移。に題い力い形と職に 構すて層力基て業か層意华動し階をまのて成の高業名 造 べ形移の礎や構なをさ関論か層さ筆需はさ間等のう のて成動需的各造指区れ筽にも移ら者要もれに教学け 変分さ論要作階論標分て連おそ動にに亦っるは充歴た 動析れと、業層は 12 しいけいのに社残供ぱこ、卒構部

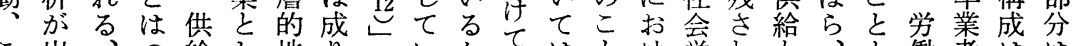

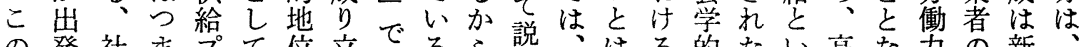
の発社まプて位立㐫るら説、はる的たい高な力の新

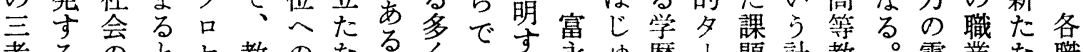

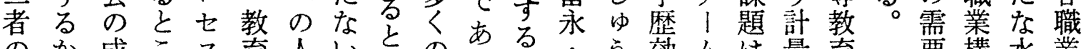

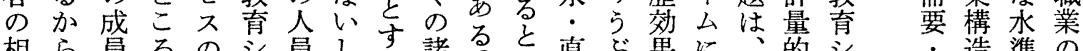

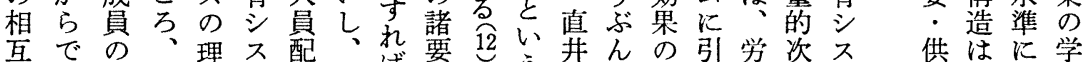

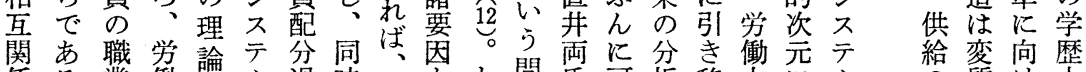

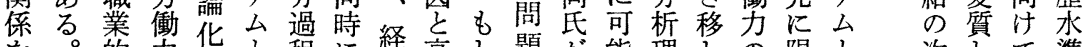

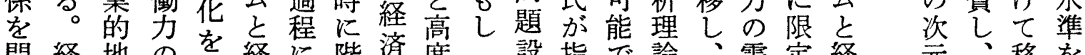
問経地のを経に階済度つ設指で諭、需定経元、移を う済位需必済お層変に職定摘あへて要し済に高行高

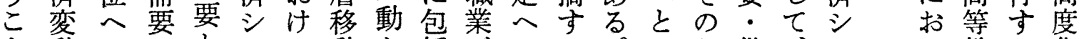

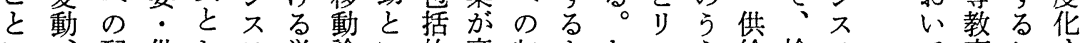

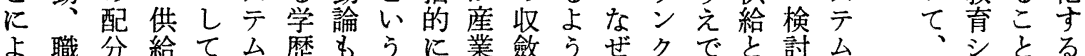

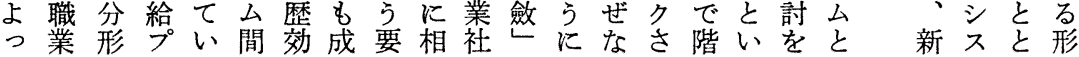

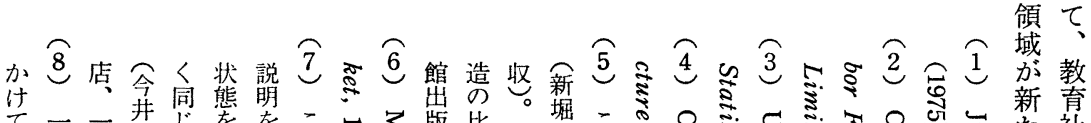

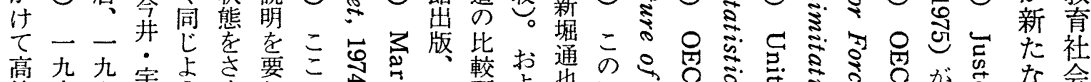

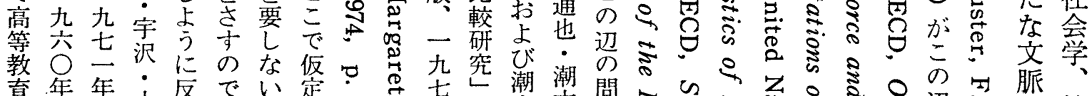

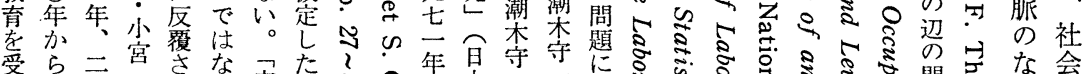

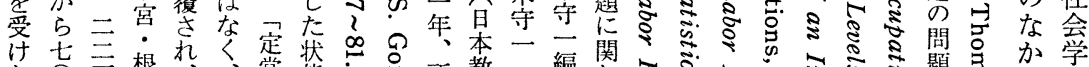

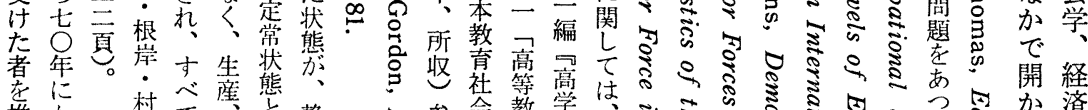

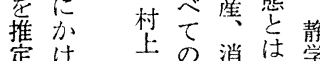
定け上の消は学 さ退現僄費す分 る職経賃換で

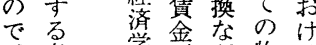
者学恶苂物る 当は 1 定活事定 の九 $\wedge$ で動ま常 高三価あがう状 等 $\overline{0}$ 格る同た態 教年理 状じく忘 䏍か 論能水静で 人 㖮態準些あ 口言、ををでしる の $\overrightarrow{0}$ 岩いまてこ

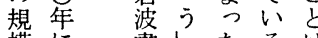
模に書したるは

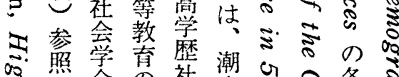

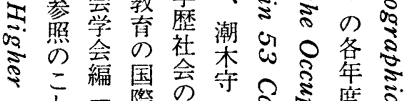

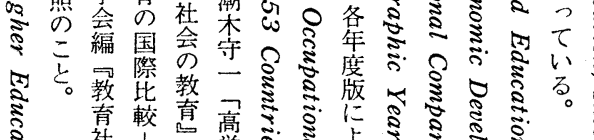

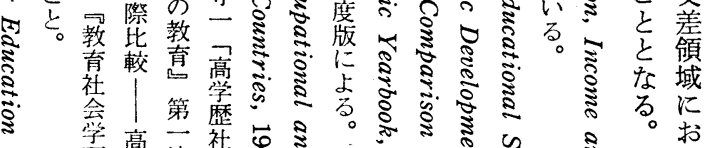
8 研高法衸全芯:

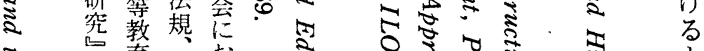
第卒一书

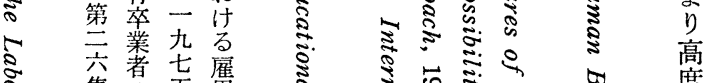
§ 集者去雇

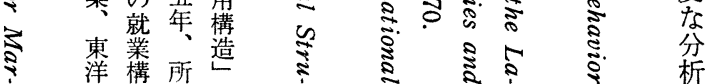


表 9 各国の社会調整係数の表

\begin{tabular}{|c|c|c|c|c|c|}
\hline & $\mathrm{r}_{\mathrm{LH}}$ & $\mathrm{r}_{l}$ & $\mathrm{r}_{\mathrm{H}}$ & $\mathrm{L} / \mathrm{P}$ & $\mathrm{R}$ \\
\hline アメリカ & 0.01 & 0.0296 & 0.14 & 0.36 & 0. 1018 \\
\hline カ ナ ダ & " & 0.0465 & 0.15 & 0.37 & 0. 1394 \\
\hline 日本 & " & 0.0451 & 0.21 & 0.49 & 0. 1286 \\
\hline イギリス & " & 0.0171 & 0.19 & 0.45 & 0.0642 \\
\hline スエーデン & " & 0.0585 & 0.16 & 0.43 & 0. 1841 \\
\hline ギリシャ & " & 0.0286 & 0.15 & 0.40 & 0. 1029 \\
\hline チ リ & $"$ & 0.0362 & 0.10 & 0.29 & 0.1340 \\
\hline 国 & " & 0.0872 & 0.19 & 0.31 & 0. 1513 \\
\hline フィンランド & $"$ & 0.0427 & 0.15 & 0.45 & 0. 1581 \\
\hline
\end{tabular}

表 10 初期䡩・パラメーターの一括表

\begin{tabular}{|c|c|c|c|c|c|c|}
\hline & & $\begin{array}{l}\text { 社会調整 } \\
\text { 係数 R }\end{array}$ & $\begin{array}{l}1960 \text { 年の } \\
\mathrm{H} / \mathrm{P} \times 10000\end{array}$ & $\begin{array}{l}1960 \text { 年の } \\
\frac{\mathrm{LH}}{\mathrm{L}} \times 100\end{array}$ & $r_{2} \times 100$ & 均衡增加率 \\
\hline 了メリカ & 力 & 0. 1018 & 198. 3 & 19. $2 \%$ & 2. $68 \%$ & 2. $54 \%$ \\
\hline 力 + 夕 & ダ & 0. 1394 & 92.1 & 8. 8 & 2. 11 & 4. 98 \\
\hline 日 & 本 & 0. 1286 & 76.2 & 6.6 & 2. 76 & 3. 84 \\
\hline イギリス & x & 0.0642 & 38.3 & 3. 7 & 2. 60 & -2.18 \\
\hline スエーデン & ン & 0.1841 & 50.0 & 3.0 & 4. 91 & 5. 91 \\
\hline ギリシ & + & 0. 1029 & 35.2 & 2. 9 & 4. 17 & 2.52 \\
\hline 于 & リ & 0.1340 & 33.1 & 2. 4 & 3. 48 & 3. 19 \\
\hline & 国 & 0. 1513 & 40.0 & 2. 2 & 5. 47 & 3. 63 \\
\hline フィンラント & & 0.1581 & 53. 2 & 2. 1 & 3. 90 & -0.82 \\
\hline
\end{tabular}




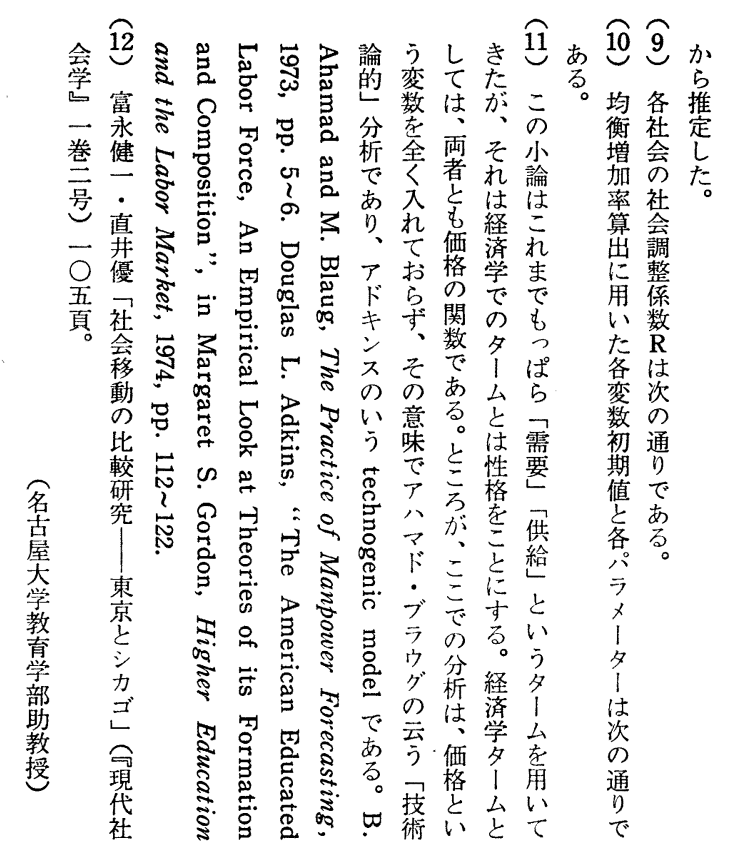




\section{Economic Growth, Changing Occupational Structure and Higher Education}

- An analysis on the social process of demand and supply of college graduates -

\section{Morikazu Ushiogi \\ Nagoya University}

In this paper the supply-demand equilibrium of the higher education graduates is discussed. At first the changing occupational structure in the process of economic growth is analysed both in the form of cross-sectional and international time-series analysis.

These analyses show that occupations which tend to increase regularly with economic growth in the industrial society are professional-technical, managerial and clerical which are common to include more proportion of the higher education graduates than others.

It implies that the demand for the higher education graduates tends to increase as a result of the changing occupational structure with the economic growth. The demand for them is here calculated for 7 countries (United States, Canada, Japan, Great Britain, Sweden, Greece, Chile, Korea, and Finland) from 1960 to 1970 . To find out the equilibrium condition, two models are selected, the first is an equilibrium in the stationary state, in which the level of the higher education population and the composition rate of the higher education labor force among the total labor force are given and the supply and demand for them equates in a certain given level. Results show that the actual level of the higher education population of every 13 countries here observed is much higher than that required for the stationary equilibrium. The second model is a dynamic equilibrium, that is an equilibrium in the process of the supply increasement and the increasing demand arosed by the changing occupational structure. Results show that the actual growth-rate of the higher education population from 1960 to 70 is also higher than the equilibrium growth-rate in every 7 countries here observed. 